\title{
The Correspondence between Johannes Hevelius and Pierre des Noyers, as the Mirror of Scientific Novelties
}

Pierre des Noyers (1608-1693), a disciple of Gilles Personne de Roberval, is the most important correspondent of Johannes Hevelius. Their correspondence consists of 257 letters, in a corpus of 2700 letters, i.e. about $10 \%$ of the total. Pierre des Noyers came to Poland with Queen Louise-Marie de Gonzague. During his Polish travels he spent some time in Gdańsk (December 1646) and met the astronomer who was a prominent member of the city elite, as one of the most important brewers. During this period, Hevelius was completing his Selenographia (1647) and Pierre des Noyers was very helpful in expanding a European network that already included Marin Mersenne and Pierre Gassendi. The relations between the two scholars were very intense. After the death of the Queen (1667), des Noyers stayed in his friend's house. The last letter is dated October 1686. Hevelius died in January 1687. Pierre des Noyers remained in Poland where he died in 1693. At this point I would like to present some conclusions based on my analysis of this correspondence, thereby introducing the third volume of the series Correspondance de Johannes Hevelius to be published in 2019 .

Keywords: Johannes Hevelius, Pierre des Noyers, Louise-Marie de Gonzague, astronomical correspondence, Republic of Letters

Słowa kluczowe: Jan Heweliusz, Pierre des Noyers, Ludwika Maria Gonzaga, korespondencja astronomiczna, res publica litteraria

Pierre des Noyers is Hevelius's most important correspondent. In the present state of research, the corpus consists of 257 letters, 158 from des Noyers and 99 from Hevelius. All Hevelius's letters are in Latin; the letters of des Noyers are in French, except for the two first ones. In the third letter, des Noyers chose to write in French: "Je crois que je m'expliqueré mieux en françois qu'en latin et vous en entendez assez pour me permettre de ne plus vous escrire en une autre langue" (11 January 1647). 
Pierre des Noyers had the opportunity to meet Hevelius during the Joyous Entry of Louise-Marie de Gonzague in Gdańsk, and he acknowledged his mastery of the French language. The royal cortege stayed in Gdańsk for ten days from 16 February to 20 February, 1646 and the celebrations were magnificent, Gdańsk being a very wealthy city.

\section{General remarks}

The correspondence covers a period of forty years. The first letter (a short undated message from des Noyers) was issued in 1646; the last letter by Hevelius, dated 18 October 1686, is probably the last letter he wrote in his lifetime. Hevelius died on 28 January 1687; des Noyers survived him by a few years; he died on 26 May 1693, at the age of 85.

This correspondence is not symmetrical: the letters from Hevelius are frequently long, while the letters from des Noyers vary from 2-3 lines to 3-5 pages.

The statute of the correspondents is also far from symmetrical; Hevelius claimed to be a scientist renowned in all the countries of Europe and considered des Noyers with some disdain, at least at the beginning of their correspondence. Des Noyers, who introduced himself as a pupil of the mathematician Roberval, was indeed the executive secretary of the Queen of Poland. He had been a member of her circle in both Nevers and Paris and accompanied her to Poland, where he died. Although he had a solid scientific background and many connections in Paris, he was never considered by Hevelius as his alter ego. Their correspondence about the experiments on the vacuum performed by Father Magni in July 1647 is unambiguous in this respect. However, the scientific training of des Noyers allowed him to become a partner to scientists and the key person of an international information network centered in Warsaw, which quickly became indispensable to Hevelius.

The exchanges, however, are not regular. As a matter of fact, not all the correspondence has been preserved in full and some letters contain allusions to documents that are today lost. There are, though, some episodes worth mentioning:

1647: the controversy over the vacuum (of slight interest to Hevelius, of primary interest to des Noyers) and the publication of Selenographia. Hevelius entrusted to des Noyers the diffusion of the book and its presentation to the King and Queen.

1653-1655: The entering of Saturn in Leo. Hevelius became acquainted with such friends of des Noyers as Davisson and Burattini. Des Noyers passed on to Hevelius numerous books, his own observations, as well as the observations of his friends on the Eclipses of the Sun and the Moon. Following the publication of Selenographia, Hevelius became able to expand his network and des Noyers, who was in charge of the diplomatic correspondence of the Queen, was now a very helpful friend.

1665-1666 is the period of the controversy on the comet of 1664-1665 and of an inaccurate observation by Hevelius that was contested by the whole scientific community. From 1663 onwards, Hevelius received gratifications from France. He published the Prodromus Cometicus (1666), dedicated to Colbert, and Mantissa, dedicated to Leopold of Toscany, where Hevelius defends his calculations. The publication of Cometographia (1668) was delayed by the quarrel. Here the correspondence of des Noyers provides us with a useful supplement to the file analyzed in volume II of the series Correspondance de Johannes Hevelius and with information on Chapelain, the dispenser of Colbert's gra- 
tifications, as well as with criticism from the young Académie des sciences (founded in 1666), particularly from Auzout and Petit, and the final rejection of Hevelius's ideas by the Royal Society. Des Noyers supplied complementary observations from his Italian network, especially from Cassini and the Jesuits.

1672: is the time of the maximus tubus. Hevelius wanted to dedicate his Machina Cœlestis to Louis XIV. In this work he described his observatory and his instruments, and his aim was to demonstrate that, despite the controversy about his observations of the comet of 1664, he owned the best performing instruments of the world, compared with the French astronomers of the Académie des sciences (e.g. Cassini, Picart, Auzout, and Huygens). The Paris Observatory had been active since 1671 and Cassini had been appointed as director. But Hevelius also claimed to surpass the achievements of Hooke and the telescope introduced by Newton in 1668. Hevelius praised the accuracy of the observations oculo nudo and his own attempts to build the longest possible tube with the help of Burattini.

1681: After the fire of 1679 that destroyed his observatory, his printing workshop, some of his observations and caused him heavy financial loss, Hevelius fought against his being marginalized in the scientific community. He was unable to print his observations of the comet of 1681, but he wrote historiolæ that were transcribed and dispatched by Pierre des Noyers.

For some years the information is very poor. For instance, in the period known as the Swedish Deluge, des Noyers followed the court in exile and the royal troops. After the death of the Queen in 1667, he inherited the starosty of Tuchola, not far from Gdańsk and had to remain there to defend his rights. Moreover, after the election of Michał Korybut Wiśniowiecki to the throne of Poland (1669-1673), the "French party" belonged to the opponents and took refuge in Gdańsk where Pierre des Noyers was living and performing observations with Hevelius.

Let us now have a closer look at the relationship between the two scientists and to the benefits Hevelius got from this correspondence in the field of information.

\section{The networks of Pierre des Noyers}

With the Polish Court:

As Karolina Targosz conclusively demonstrated, Queen Louise-Marie de Gonzague had organized a so-called "learned court".

Italians were numerous, especially during the reign of Ladislas IV, the first husband of Louise-Marie. Most of them were tradesmen, especially in luxury goods. They also exploited mines and managed post offices. They often gave loans to the King. The Italians were a minority in Gdańsk, which was a Lutheran city with an important German community and a powerful minority of Dutch and Calvinist origin. Although Gdańsk was a major commercial city, Italian trading networks were mainly present in Warsaw and Cracow.

Among the friends of des Noyers three Italians were of special importance. Girolamo Pinocci from Lucca was a merchant of precious textiles. A citizen of Cracow in 1644, he became first Councilor and finally Syndic and secretary of the Chancellery (Lwów). He was entrusted with important diplomatic tasks such as preparing the candidacy of Ma- 
thias de Medici to the throne of Poland and other affairs in England and Holland in 1658 and 1659. He was awarded indigenate (noble citizenship) in 1662. He owned one of the greatest libraries in Poland where books of magic, alchemy, astrology and astronomy were especially plentiful. Burattini visited him in Cracow in 1642.

Niccolo Tito Livio Burattini is another important personality. An adventurer and a polymath, he was more interested in science and antiquity than in trade and he spent four years in Egypt (1637-1641) before coming to Cracow and starting a brilliant career. Thanks to the protection of the Queen, he was appointed as Royal Architect in 1652 and received the mining concessions of Olkusz (1652) and Zawadów (1653). Finally, he became, with the mathematician Paolo del Buono, master of the Royal Mint in Cracow. On 30 August 1658 he became a knight and was awarded indigenate.

Having full responsibility of the Mint in 1659, he helped the King to finance the war effort by stamping copper coins. This resulted in inflation, ruining the nobility, which in turn launched a series of trials against him. He also was in charge of several diplomatic missions: in Paris with des Noyers in 1650, but also in Italy in order to make the first contacts with Mathias de Medici and also to negotiate the sale of the jewels of the Queen during the so-called Swedish Deluge. During these travels he met de Medici but also Father Riccioli in Bologna, and Cassini. He became well acquainted with the new instruments built by Eustachio Divini and Giuseppe Campani. He was also interested in various technologies. When he arrived in Cracow, he became assistant to the rector of the Jagiellonian University, Stanislas Pudłowski. It was there that he studied the works of Galileo and developed his hydrostatic theories in his Bilancia sincera (1645). In 1647 he constructed his famous "flying drake" but he devoted most of his time to constructing telescopes, polishing lenses, to optics and observations of the heavens. He built an observatory and workshops at Ujazdów near Warsaw. He provided Hevelius with apparatus (lenses, maximus tubus) but, above all, he was a friend of des Noyers and Hevelius could only make contact with him through des Noyers.

Pinocci is not often mentioned in the correspondence of Hevelius (three letters, in 1666); Burattini more frequently (nineteen letters in the period 1650-1682). But des Noyers was closely linked to each of them and used their networks extensively in order to be aware of the Italian scientific novelties and to inform Hevelius about them.

The third personality illustrating the Italian networks of des Noyers is Francesco Gratta, belonging to a family of the Duchy of Milano. His father had begun his career in the Neri Company, a trader in grain and the representative of the Grand Duke of Tuscany. Thanks to his connections with the court, he was appointed head of the post offices in Gdańsk (1664) and had to organize the mail services in Royal Prussia, Courland and Livonia. Pierre des Noyers constantly relied on him, but Hevelius did not like him. This feeling was mutual, hence Gratta was never in a hurry to deliver any letters sent by Hevelius to des Noyers and vice versa.

Thanks to his large network, des Noyers was able to mobilize scientists in Venice, Florence, Lucca, Genova and of course the Jesuit group in Rome.

With the Jesuits:

As a Lutherian, Hevelius had very few contacts with the Jesuits. In this world, Pierre des Noyers was also very helpful. Des Noyers himself, as well as the Queen of Poland, had 
a strong sympathy towards Jansenism, the Queen contributing to the diffusion in Poland of the works of Jansenius and of Arnauld's Fréquente communion. She corresponded regularly with Mère Angélique who gave her an edition of the Provinciales of Pascal. Nevertheless, the Jesuits played a prominent role at the court thanks to the support of King John Casimir, a former Jesuit himself who lived surrounded by Jesuits. As diplomat and representative of the court, des Noyers was welcome in the Jesuit networks and regularly passed on to Hevelius the observations he received from Bologna (Riccioli), from Rome (Kircher, de Gottignies) or even from Germany (Cologne and Munster for instance). Thanks to des Noyers, Hevelius was informed of the research activities and publications of the Jesuits.

\section{With France:}

In his correspondence Hevelius does not utter a single word to des Noyers about the letters he exchanged with Gassendi and Mersenne (although des Noyers new Mersenne). He would ask for books he had already received, and complained about the delays. The same silence can be observed about his intrigues at the court of France and with Chapelain. When he questioned des Noyers about the titles of Colbert, this was only a technical question in connection with the dedication of his Prodromus Cometicus. It was only after the fire of 1679 that he raised the question of remuneration and asked des Noyers to use his influence among his French friends in order to get the promised money. After having being listed for the said remuneration, he nevertheless requested his friend to offer his Selenographia to the King and his entourage during his stay in Paris in 1664 (29 February 1664).

Hevelius was in contact with Boulliau before des Noyers wrote on his behalf during his visit to Paris in 1650. At the beginning of the correspondence, Boulliau was travelling in Italy and in the Levant (1646-1647). Gassendi informed Hevelius about that. Later on, Boulliau used to send observations to Hevelius, mostly via des Noyers with whom he conducted a weekly exchange of letters. Boulliau came to Poland in 1661, invited by the Queen of Poland on the advice of des Noyers. He stayed twice in Gdańsk, in March-April and then in September, but he remained, above all, the correspondent of des Noyers. As a matter of fact, des Noyers was a sort of letterbox. His position at the court allowed him to use diplomatic mails and to rely on many contacts to dispatch books and packages. Boulliau was also a friend of Chapelain who often mentions his interventions in his letters to Hevelius. There is, however, no question of that in the letters between Hevelius and des Noyers, although there is also some evidence that Hevelius kept to himself the delicate question of his contacts with the court of France. A good number of the letters sent by Boulliau were destined for des Noyers who in turn passed them on to others; in other cases there are only fragments or isolated observations sent by des Noyers as enclosed pieces. Very few are still extant. Even before the Holland War (1672-1678), the letters of Boulliau did not go through Warsaw but were sent directly to Gdańsk. Des Noyers asked his friend Gratta to give them to Hevelius to read before sending them back to him. As far as the relationship with France is concerned, des Noyers was useful but not indispensable. He simply made the exchange with Boulliau easier, while Hevelius reserved for himself the exchanges with Chapelain, Perrault and the other agents of Colbert. 
As said above, des Noyers spent quite a lot of his time collecting books and observations for Hevelius. The most frequent verbs occurring in the letters are "to send" and "to transmit", and all the letters were sent together with packages or pieces of works. Hevelius on his part sent to des Noyers his last publications or observations to be distributed by him to their scientific partners. A good deal of the correspondence concerns mail, lost packages, or books which never arrived. Des Noyers was indeed in charge of the diffusion of Hevelius works in Italy and in the Holy Roman Empire.

The packages were mailed separately. One can only make conjectures about the exchange of books from abridged titles or wrong spellings of names (des Noyers often wrote phonetically). Some books were personally sent to des Noyers and Hevelius was only allowed to borrow them.

The question of enclosed documents is somewhat different. Numerous observations were used by Hevelius for his own publications and were withdrawn from the correspondence. Among the remaining ones, Libri committed a number of thefts, especially of the papers illustrated by drawings. It is in fact very difficult to connect a particular letter to a document written by a third person (if available). I was able to identify the drawing of a Campani Telescope (for Leopoldo de Medici) thanks to an observation of Saturn, forgotten in the Libri papers, because des Noyers explained that the first mail had got wet and that he had to draw it again.

Although some of the enclosed documents have been reproduced in the Bibliothèque nationale de France volumes, they have not been identified. When I was lucky enough to discover one of them, I added the appropriate information at the bottom of the letter. But such an identification is always delicate. The drawings, however, have never been reproduced by the Bibliothèque nationale de France copyists. But this may happen in the future. For instance, letters containing observations which were addressed to des Noyers were copied by him for Hevelius. We have done some brief editorial work on these documents.

Finally, des Noyers received from Boulliau letters destined for him, but to be used by Hevelius (sent to him as enclosed documents). In the inventory of the Prolégomènes critiques, they are listed under the heading Boulliau. He also received from Boulliau letters directly addressed to Hevelius. Such letters, apart from rare exceptions, have not been edited in the present volume.

On the other hand, Boulliau did not preserve the minutes of his correspondence (like Hevelius and Chapelain did) and the Boulliau collection of the Bibliothèque nationale de France mostly contains the letters received (not the letters sent). An edition of the Hevelius-Boulliau correspondence should be a necessary complement to the present volume.

My edition of the Hevelius-des Noyers correspondence will consist of two volumes (taking into account the number of footnotes that this requires). The letters are edited in chronological order, but only the letters of Hevelius and des Noyers stricto sensu are numbered. The enclosed documents are described at the bottom of the letter in question. The other documents can be found in their chronological place, but without any number.

In conclusion, this correspondence was very important for Hevelius, but it consists mainly in accompanying letters. Scientific debates are rarely dealt with. But these letters 
allow us to follow the circulation of scientific information before and after the founding of the Academies. This information was of primary interest for Hevelius who was isolated, working in a peripheral city and not always very clever in his diplomatic relations with colleagues he often considered as rivals. Obviously, Pierre des Noyers helped him to avoid many quarrels.

\section{Bibliography}

Frost R., After the Deluge. Poland-Lithuania and the Second Northern War, 1655-1660, Cambridge 1993.

Correspondance de Johannes Hevelius. Tome I: Prolégomènes critiques, ed. by Ch. Grell, Turnhout 2014.

Correspondance de Johannes Hevelius. Tome II: Correspondance avec la cour de France et ses agents avec un dossier sur la querelle de la comète de 1664-1665, ed. by Ch. Grell, Turnhout 2017.

Mazzei R., Traffici e uomini d'affari italiani in Polonia nel Seicento, Milan 1983.

Nellen H.J.M., Ismaël Boulliau (1605-1694), astronome, épistolier, nouvelliste et intermédiaire scientifique, Amsterdam, Maarsen 1994.

Salamonik M., In their Majesties' Service. The Career of Francesco de Gratta (1613-1676) as a Royal Servant and Trader in Gdańsk, Huddinge 2017.

I. Tancon, Lo scienzato Tito Livio Burattini (1617-1681) al servicio dei Re di Polonia, Trento 2006.

Targosz K., La Cour savante de Louise-Marie de Gonzague et ses liens scientifiques avec la France, 1646-1667, Wrocław 1982.

CHANTAL GRELL is a Professor of early modern history at the University of Versailles. Her research focuses on historiography, intellectual history and the history of the European courts. She is the editor of the first volume of the series Correspondance de Johannes Hevelius (Prolégomènes critiques, 2014) and recently published the second volume, devoted to the correspondence of Hevelius with the French Court (2017). She is working now on the correspondence between Hevelius and Pierre des Noyers. E-mail: chantal.grell@gmail.com 